\title{
Review
}

\section{Ethnic Variation in the Manifestation of Parkinson's Disease: A Narrative Review}

\author{
Aaron Ben-Joseph $^{\mathrm{a}}$, Charles R. Marshall ${ }^{\mathrm{a}}$, Andrew J. Lees ${ }^{\mathrm{b}}$ and Alastair J. Noyce ${ }^{\mathrm{a}, \mathrm{b}, *}$ \\ ${ }^{a}$ Preventive Neurology Unit, Wolfson Institute of Preventive Medicine, Queen Mary University of London, \\ London, UK \\ ${ }^{\mathrm{b}}$ Reta Lila Weston Institute of Neurological Studies and Department of Clinical and Movement \\ Neurosciences, University College London, London, UK
}

Accepted 27 October 2019

\begin{abstract}
The global prevalence of Parkinson's disease is increasing, yet the characteristics, risk factors and genetics of PD in Black, Asian and Hispanic populations is little understood. In this paper we review the published literature on clinical variation in the symptoms and signs of Parkinson's disease in different ethnic groups and responses to treatment. We included any study that sampled patients with Parkinson's disease from distinct ethnic backgrounds. We conclude that whilst there is little published evidence for ethnic variation in the clinical features of Parkinson's disease, there are substantial limitations and gaps in the current literature, which mean that the evidence does necessarily not fit with clinical observation. Possible explanations for expected differences in manifestation include genetic determinants, the co-existence of cerebrovascular disease and/or Alzheimer's disease pathology, healthcare inequalities and socio-cultural factors.
\end{abstract}

Keywords: Parkinson's disease, ethnic groups, epidemiology, tremor, dementia, atypical parkinsonism

\section{INTRODUCTION}

Health inequalities related to ethnicity are well recognized in clinical medicine and healthcare settings, and persist in the current era. Much of our understanding of chronic disease comes from the clinical study of White patient groups. Revolutionary advances in population-level genetics and molecular biology have not been met with similar revolution in inclusivity in research, contributing to enduring health inequalities. Ethnic inequality in inclusion in genome wide association studies is particularly stark [1]. The Parkinson's disease (PD) research community has colluded. The global prevalence of PD doubled between 1990 and

${ }^{*}$ Correspondence to: Dr. Alastair Noyce, MRCP, PhD, Preventive Neurology Unit, Wolfson Institute of Preventive Medicine, Barts and the London School of Medicine and Dentistry, Queen Mary University of London, London, EC1M 6BQ, UK. Tel.: +44 207882 3527; E-mail: a.noyce@qmul.ac.uk.
2016 and is projected to double again over a similar interval; making PD the fastest growing neurological disorder [2, 3]. For a global phenomenon, little is understood about differing manifestations of PD in different ethnicities, including issues around diagnosis and response to treatment. Most published PD research comes from the USA and Europe, and study of mainly White subjects. Even in this group the clinical features and speed of deterioration are highly heterogenous. Attempts to disentangle heterogeneity have led to subtyping PD patients by age of onset, motor symptoms, non-motor symptoms, rate of progression, genetics and combinations of these factors [4-13].

Clinical experience and emerging evidence suggest that ethnicity is a further key determinant of heterogeneity, with differences in epidemiology, clinical manifestations and mortality observed. However, variation by ethnicity is still far from being 
understood, and the studies to date report apparently contradictory findings. This review aims to summarise the evidence thus far, and outline the key directions for future research.

\section{SEARCH STRATEGY}

The Medline database (Pubmed) was searched for all articles up to April 2019. The search string included the following terms: "Parkinson's", "ethnicity", "ethnic", "race" and "racial". We excluded any studies that identified patients based on genotype alone or the presence of a particular symptom (e.g., PD patients with REM sleep behaviour disorder). When mono-ethnic studies were reviewed the search string included the term "Parkinson's" followed by terms related to the specific area we were searching for. For example, when searching for mono-ethnic studies that measured motor subtype in PD samples we searched for the terms; "type", "sub type", "subtype", "sub-type", "motor", "postural instability", "rigid akinetic", "rigid-akinetic", "rigid-akinesia", "rigid akinesia", "tremor-dominant" and "tremor dominant". We also reviewed the references of these articles to identify any other relevant articles that may have been missed. Two papers were excluded that were not written in English and had no translation available, but these were mono-ethnic studies in small samples so are unlikely to substantially alter the conclusions of this article.

\section{EPIDEMIOLOGY OF PD}

The prevalence of PD appears to vary geographically [14]. The main risk factor for PD is increasing age meaning that geographical regions with older populations and higher life expectancy tend to have a higher prevalence of PD [14, 15]. However, geographic differences persist even when controlling for these factors, which suggests that ascertainment, genetic factors and competing morbidity may be important determinants [16-18]. Most studies report the highest prevalence of PD in White populations (for example 1,671.63/100,000, compared with $1,036.41 / 100,000$ in Blacks, and 1,138.56/100,000 in Asians) [19, 20]. Geographical location is a stronger determinant of PD risk than ethnicity. The prevalence of PD in Black-Africans residing in subSaharan Africa $(40 / 100,000)$ is much lower than the prevalence of PD amongst people of African origin living in the USA [18]. It is interesting to note that in the only published neuropathological study comparing neurologically normal White British and Black Nigerian brains a similar prevalence of incidental Lewy body disease at autopsy was found. Although these participants were not age-matched the mean age of Nigerian brains in the study was 68.8 years and the prevalence of Lewy bodies was $5.3 \%$. The prevalence of Lewy bodies in 70-79 year olds in Europe and North America was found to be 4.7\%. [21, 22]. Extrapolating from this it implies that at least some of the observed differences in the prevalence of PD might be related to case ascertainment.

\section{MORTALITY}

Several studies have reported ethnicity to be a predictor of mortality in PD. Black patients tend to have a slightly higher risk of death than White patients and this finding has been replicated across several studies [23-26]. When comparing mortality occurring after hip and pelvic fractures in PD patients Black patients also have a higher adjusted hazard ratio of mortality (HR 1.12; 95\% CI 1.09-1.16), whereas rates may be lower in Hispanic patients (HR 0.87; 95\% CI 0.81-0.95) [27]. In general, compared to White patients, Hispanic patients have a lower risk of death (HR 0.72; 95\% CI 0.65-0.80) and the same may be true of Asian patients (HR 0.86 ; 95\% CI 0.82-0.91) [23]. However, other studies have found contrasting results $[28,29]$. This is in contrast to Alzheimer's disease (AD) where White patients have a shorter length of survival from diagnosis (median 3.1 years) compared to Black and Hispanic patients with $\mathrm{AD}$ (3.7 and 4.1 years respectively) [30].

\section{ETHNIC VARIATION IN THE MOTOR SYMPTOMS OF PD}

The first reports of an atypical Parkinsonian phenotype in Black populations were from the French Antilles. It was noted that most patients had a bradykinesia-dominant disease with reduced response to levodopa and earlier dementia [31-33]. Although there is some evidence to suggest Guadeloupean-Parkinsonism may be a distinct clinico-pathological entity, Chaudhuri et al. reported an increase in atypical features (levodopa hypo-responsiveness and bradykinesia-dominant) of 
Table 1

Motor sub-type in de novo PD cases by country

\begin{tabular}{|c|c|c|c|c|c|c|c|c|c|c|c|c|}
\hline$\underset{\tilde{D}}{\stackrel{2}{\Xi}}$ & 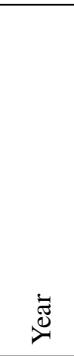 & $\stackrel{\overparen{\Xi}}{\Xi}$ & 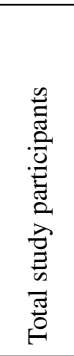 & 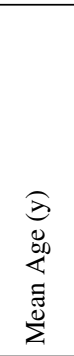 & $\sum_{\substack{x \\
\vdots}}^{L}$ & 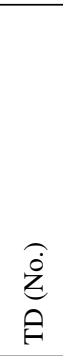 & $\underbrace{8}_{0}$ & 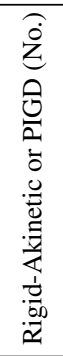 & 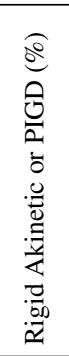 & 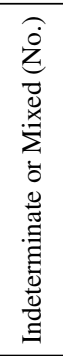 & 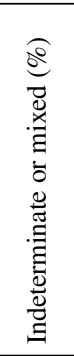 & Method of Subtyping \\
\hline Reinoso & 2014 & Singapore & 576 & 63.8 & $328 / 248$ & 19 & 3.3 & 383 & 66.5 & 174 & 30.2 & $\begin{array}{l}\text { Lewis method and Rossi } \\
\text { modifications }\end{array}$ \\
\hline Rajput & 2017 & Canada & 156 & 65.0 & $98 / 58$ & 10 & 6.4 & 45 & 28.8 & 101 & 64.7 & Novel method \\
\hline Ramani & 2016 & UK & 42 & 67.0 & $29 / 13$ & 7 & 16.7 & 17 & 40.5 & 18 & 42.9 & Novel method \\
\hline Poletti & 2011 & Italy & 42 & 65.0 & $28 / 14$ & 10 & 23.8 & 24 & 57.1 & 8 & 19.0 & Lewis method \\
\hline Alves & 2006 & Norway & 171 & 71.3 & $112 / 87$ & 43 & 25.1 & 92 & 53.8 & 36 & 21.1 & Jankovic \\
\hline Auyeung & 2012 & Hong Kong & 171 & 62.2 & $93 / 78$ & 46 & 26.9 & 62 & 36.3 & 63 & 36.8 & Novel method \\
\hline Yuan & 2013 & China & 51 & 61.9 & $24 / 24$ & 20 & 39.2 & 19 & 37.3 & 12 & 23.5 & $\begin{array}{l}\text { Jankovic method with } \\
\text { Korchovinov modifications }\end{array}$ \\
\hline Mocciia & 2016 & Italy & 63 & 60.6 & $38 / 25$ & 27 & 42.9 & 18 & 28.6 & 18 & 28.6 & Jankovic \\
\hline Konno & 2018 & USA & 1003 & 64.0 & $637 / 366$ & 439 & 43.8 & 386 & 38.5 & 178 & 17.7 & $\begin{array}{l}\text { Most prominent symptom at } \\
\text { diagnosis }\end{array}$ \\
\hline Seong-Min Choi & 2018 & South Korea & 192 & 66.2 & $94 / 98$ & 87 & 45.3 & 82 & 4.1 & 23 & 12.0 & Jankovic \\
\hline Moretti & 2012 & Italy & 103 & 64.1 & $60 / 43$ & 47 & 45.6 & 56 & 54.4 & & 0.0 & $\begin{array}{l}\text { Most prominent symptom at } \\
\text { diagnosis }\end{array}$ \\
\hline Appleman & 2011 & USA & 35 & 66.2 & $22 / 13$ & 16 & 45.7 & - & - & 19 & 54.3 & $\begin{array}{l}\text { First symptoms noticed by } \\
\text { patient }\end{array}$ \\
\hline Muller & 2011 & Norway & 207 & 67.9 & $122 / 85$ & 95 & 45.9 & 88 & 42.5 & 24 & 11.6 & Jankovic \\
\hline Hiorth & 2013 & Norway & 207 & 67.9 & $122 / 85$ & 95 & 45.9 & 89 & 43.0 & 23 & 11.1 & Novel UPDRS ratio \\
\hline Aygun & 2014 & Turkey & 104 & 66.5 & $68 / 36$ & 57 & 54.8 & - & - & 47 & 45.2 & $\begin{array}{l}\text { Most prominent symptom at } \\
\text { diagnosis }\end{array}$ \\
\hline Nicoletti & 2016 & Italy & 485 & 65.6 & $292 / 193$ & 311 & 64.1 & 104 & 21.4 & 70 & 14.4 & $\begin{array}{l}\text { Most prominent symptom at } \\
\text { diagnosis }\end{array}$ \\
\hline
\end{tabular}

TD, tremor dominant; PIGD, postural instability and gait disorder; Lewis method with Rossi modifications, ratio of the mean tremor scores (TD) (items 20,21) and the mean Akinetic-rigid score (AR) (items 18, 19, 22, 27-31): if the ratio TD/AR > 2.0 it was defined as TD and if AR/TD more than 2.0 was defined as AR, and mixed type was any indeterminate result. Jankovic, Ratio of mean TD scores divided by mean of postural instability and gait items (falling, freezing, subjective gait difficultly, gait and postural instability): if ratio $>1.5$ TD PD, if ratio $<1.0$ PIGD PD. Other subtyping methods are as described in the reference materials.

PD in London's African and African-Caribbean population [34]. These early reports of atypical PD in Black patients are in keeping with our anecdotal experience of a rigid-akinetic dominant PD phenotype in Black and South Asian PD patients and one study has shown Asian patients may be more likely to experience freezing of gait [35]. However, in contrast to our clinical impression, a comparison of Italian and Ghanaian PD patients found that the Ghanaian patients were more likely to have a tremordominant PD subtype $(74.7 \%$ vs $52.2 \%, p<0.001)$ [36].

There are only a few studies that have compared motor symptoms or subtypes in an ethnically diverse sample of patients with PD. To explore the matter further, we compared proportions of motor subtypes in several mono-ethnic studies from around the world.
Table 1 shows the proportions of each motor subtype where the motor subtype was determined in de novo PD cases [11, 28, 37-68]. It is clear that the prevalence of each motor subtype varies between studies, but it is difficult to determine patterns or correlations from these data. This is in part due to a lack of a standardised methodology for determining motor subtype and differing inclusion/exclusion criteria which confound attempts to interpret the data in a meaningful way.

There may be ethnic variation in the motor complications of PD treatment. Dyskinesia and 'wearing off' have been extensively studied in PD patients from North America and Europe, but research on this topic is patchy in other regions of the world, especially in multi-ethnic cohorts. Asian patients appear most likely to experience dyskinesia and as 
a consequence lower doses of dopaminergic drugs are often recommended [35, 69]. In an international survey Japanese physicians reported the lowest prevalence of dyskinesia in their patients. However, they were also the least likely to use levodopa monotherapy, preferring a combination of dopamine agonists and levodopa, which could be a contributing factor [70].

\section{ETHNIC VARIATION IN NON-MOTOR SYMPTOMS OF PD}

In the past two decades, there has been significant progress in the understanding of the non-motor manifestations of PD [71]. However, there remains relatively few studies that compare non-motor symptom prevalence in ethnically diverse samples. The Non-Motor Symptom Questionnaire was designed and validated in 2006 and has been used in different populations to enable comparison (see Table 2) [72-84]. All patients, regardless of ethnicity, appear to suffer from a high burden of non-motor symptoms. It is notable in Table 2 that the prevalence of gastrointestinal non-motor symptoms appear to be highest in the East Asian studies [73, 81]. The prevalence of depression was above $60 \%$ in the Chinese, Korean, Mexican and Peruvian studies [73, 77, 80, 81], but in the studies from the UK and the USA the rate was less than $40 \%$ [82, 84]. A study comparing mood and anxiety symptoms in a multi-ethnic sample found no clear differences [85].

Excessive daytime sleepiness may be more common in PD patients from Europe and North America. Studies in Asian countries suggest a prevalence in the range of 15-32\% of patients. [86-89] Whereas studies in North America and Europe suggest a prevalence of EDS between 41-57\% [90-95].

Impulse control behaviours (ICB) in PD are an important complication of dopaminergic replacement therapy (particularly dopamine agonists). It is not currently clear whether certain ethnicities are more prone to ICBs, but there may be differences in the most common impulsive behaviours in different regions that could be culturally driven as demonstrated in Table 3 [96-116]. Some of the ICBs that are reported in the literature seem to be exclusive to particular cultures, for example, Otmani et al., report an "ICB mimic" that had not been reported in the literature before; excessive Qur'an reading [103].

\section{ETHNIC VARIATION IN COGNITION IN PD}

Cognitive impairment is one of the most frequent and disabling non-motor symptoms of PD [117]. The typical cognitive domains affected by PD dementia are visuospatial, executive and attention, but there can be global deficits, particularly in advanced disease. Cognitive dysfunction frequently occurs in combination with neuropsychiatric features including depression, anxiety, hallucinations and apathy, which are major determinants of morbidity [118]. The presence of cognitive impairment with a diagnosis of PD is established as a significant indicator of increased mortality [119-121].

There is evidence that Black patients with PD have higher rates of cognitive decline and progression to dementia than other ethnic groups. Chaudhuri et al. first noticed this in 2000 in London's Black population [34] and this observation has since been substantiated by large-scale health record studies. A retrospective cohort study using the Medicare database followed up all patients with incident PD in 2002 over a six-year period $(n=138,728)$. $70 \%$ of the whole sample was diagnosed with dementia by the end of the study, and the proportion was highest in Black patients [23]. Black PD patients also have higher odds of bring prescribed dementia medications (OR 1.33, 95\% CI 1.28-1.38) compared with White PD patients which may reflect increased cognitive dysfunction [122]. Overall, unlike the inconsistencies of other non-motor and motor symptoms, current evidence supports the notion that Black patients are more at risk of dementia and cognitive impairment than White patients.

Similar findings have been observed for Hispanic patients in some settings [23]. Hispanic patients may have a more severe form of PD dementia and/or an increased severity of behavioural and psychological symptoms in dementia [122]. The evidence regarding Asian PD patients and cognitive dysfunction is more conflicting. Willis et al. found in their 6-year retrospective cohort study that Asian patients had the lowest odds of being diagnosed with dementia during the study period (OR 0.89, 95\% CI, 0.79-0.99) [23]. But Asian PD patients report higher levels of subjective cognitive impairment than White patients [35]. It remains to be determined whether Asian patients suffer from different rates of cognitive dysfunction compared to other ethnicities. This is particularly true for South Asian populations that have largely been unstudied. 
Table 2

Non-motor symptoms questionnaire (NMSQ) results by country

\begin{tabular}{|c|c|c|c|c|c|c|c|c|c|c|c|c|c|c|c|c|c|c|c|c|c|c|c|c|c|c|c|c|c|c|c|c|c|c|}
\hline 竧 & 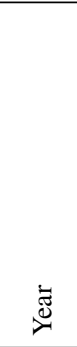 & $\begin{array}{l}\vec{E} \\
\stackrel{\Xi}{0}\end{array}$ & 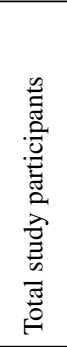 & 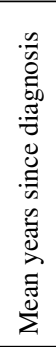 & $\begin{array}{l}\underset{8}{8} \\
\stackrel{0}{0} \\
0 \\
0 \\
0\end{array}$ & 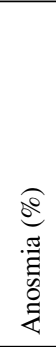 & 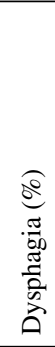 & $\begin{array}{l}\widehat{d} \\
\vec{z} \\
z\end{array}$ & 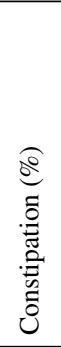 & 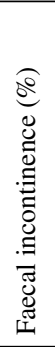 & 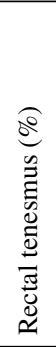 & 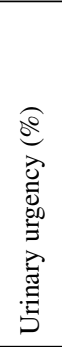 & 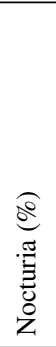 & 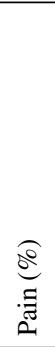 & 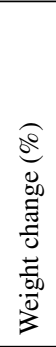 & 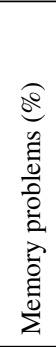 & 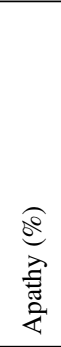 & 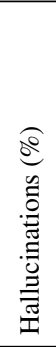 & 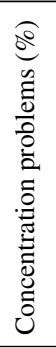 & 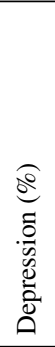 & $\begin{array}{l}a \\
\frac{a}{d} \\
\frac{0}{x} \\
e\end{array}$ & 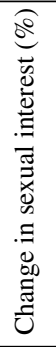 & 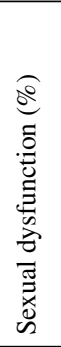 & 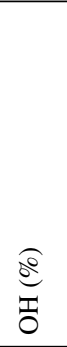 & 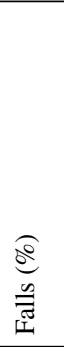 & $\begin{array}{l}\hat{e} \\
\tilde{e} \\
\stackrel{n}{1}\end{array}$ & 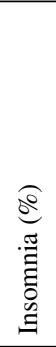 & 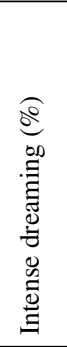 & $\begin{array}{l}\hat{e} \\
\hat{a} \\
\hat{a}\end{array}$ & 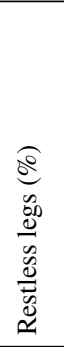 & 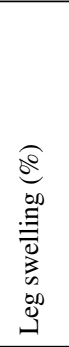 & 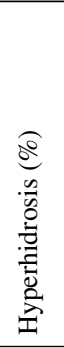 & 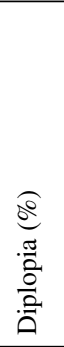 & 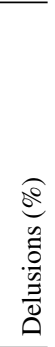 \\
\hline Dunc & 2014 & UK & 158 & 0.5 & 55 & 44 & 20 & 9 & 42 & 6 & 32 & 46 & 25 & 54 & 23 & 54 & 27 & 22 & 29 & 37 & 42 & 18 & 21 & 32 & 23 & 25 & 18 & 30 & 35 & 27 & 27 & 10 & 10 & 1 \\
\hline Rom & & US & 70 & 3.8 & 2 & 21 & 16 & 16 & 3 & 7 & 4 & 59 & 8 & ) & 21 & 42 & 29 & 12 & 39 & 38 & 36 & 36 & 42 & 38 & 10 & 4 & 41 & 34 & 38 & 47 & 12 & 19 & 15 & 1 \\
\hline Hui-j & 15 & Chin & 82 & 5.1 & 4 & 45 & 33 & 22 & 6 & 2 & 44 & 55 & 7 & 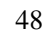 & 29 & 95 & 72 & 15 & 33 & 7 & 61 & 49 & 50 & 38 & 6 & 73 & 78 & 83 & 2 & 76 & 7 & 65 & 39 & 42 \\
\hline Cosenti & 13 & Peru & 300 & 5.8 & 3 & 36 & 22 & 14 & 5 & 7 & 41 & 66 & 7 & 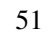 & 53 & 61 & 44 & 20 & 50 & 1 & 61 & 55 & 46 & 48 & 30 & 3 & 48 & 33 & 36 & 52 & 16 & 43 & 13 & 10 \\
\hline Khed & 13 & gypt & 112 & 6.2 & 3 & 10 & 4 & 11 & 5 & 5 & 16 & 55 & 60 & 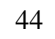 & 33 & 30 & 38 & 13 & 42 & 7 & 0 & 46 & 43 & 54 & 39 & 9 & 46 & 19 & 5 & 15 & 17 & 21 & 7 & 10 \\
\hline Chec & 8 & K & 74 & 6.4 & 3 & 28 & 1 & 23 & 66 & 5 & 39 & 55 & 8 & 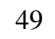 & 35 & 61 & 53 & 18 & 51 & 5 & 48 & 35 & 37 & 4 & 38 & 26 & 56 & 40 & 5 & 67 & 31 & 60 & 41 & 8 \\
\hline Rod & 11 & ex & 232 & 6.6 & 2 & 34 & 3 & 6 & 58 & 10 & 38 & 60 & 2 & 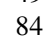 & 28 & 47 & 4 & 19 & 39 & 67 & 45 & 37 & 37 & 46 & 36 & 8 & 47 & 38 & 3 & 47 & 24 & 39 & 18 & 10 \\
\hline Mar & & Inter & 545 & 7 & 4 & 29 & 8 & 14 & 53 & 8 & 30 & 56 & 2 & 9 & 18 & 45 & 35 & 23 & 46 & 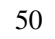 & 45 & 34 & 32 & 28 & 28 & 31 & 46 & 34 & 6 & 42 & 31 & 30 & 20 & 11 \\
\hline Tanv & 2018 & Pakis & 97 & 7 & 3 & 26 & 28 & 24 & 60 & 24 & 26 & 62 & 77 & 7 & 38 & 59 & 42 & 30 & 35 & 52 & 40 & - & - & 53 & 46 & 41 & 53 & 35 & 6 & 42 & 32 & 37 & 13 & 23 \\
\hline Bost & & Greece & 166 & 7.1 & 19 & 26 & 14 & 11 & 46 & 1 & 24 & 54 & 52 & 18 & 7 & 31 & 13 & 2 & 17 & 42 & 38 & 37 & 33 & 28 & 8 & 9 & 26 & 33 & 27 & 29 & 18 & 21 & 11 & 2 \\
\hline Chaudhuri & 2010 & $\begin{array}{l}\text { UK, Germany, } \\
\text { Spain }\end{array}$ & 242 & 8 & 42 & 43 & 27 & 16 & 48 & 6 & 27 & 60 & 65 & 46 & 23 & 51 & 34 & 17 & 50 & 49 & 42 & 37 & 34 & 39 & 29 & 35 & 47 & 35 & 39 & 41 & 38 & 31 & 18 & 10 \\
\hline Mukhtar & 2018 & Pakistan & 85 & - & 28 & 29 & 17 & 10 & 56 & 6 & 11 & 35 & 49 & 30 & 20 & 45 & 29 & 8 & 16 & 47 & 36 & 30 & 30 & 40 & 19 & 13 & 29 & 22 & 11 & 22 & 14 & 24 & 14 & 8 \\
\hline
\end{tabular}

$\mathrm{N \& V}$, nausea and vomiting; OH, orthostatic hypotension; EDS, excessive daytime sleepiness; RBD, REM sleep behaviour disorder. Any data that was not available is replaced with a dash. 
Table 3

Impulse control behaviours by country

\begin{tabular}{|c|c|c|c|c|c|c|c|c|c|c|c|c|c|c|}
\hline $\begin{array}{l}\vec{B} \\
\vec{E}\end{array}$ & 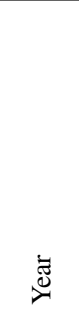 & $\begin{array}{l}\hat{E} \\
\text { 音 } \\
\text { D }\end{array}$ & 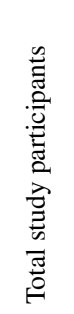 & 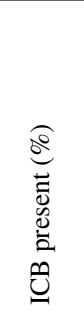 & 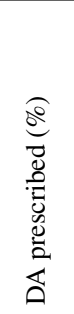 & 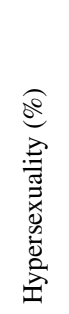 & 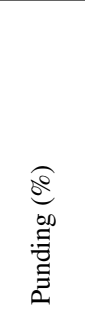 & 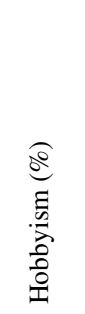 & 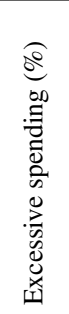 & 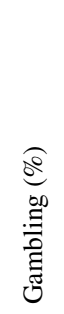 & 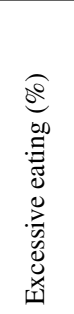 & 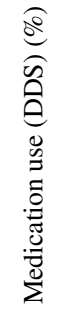 & 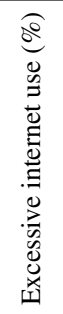 & 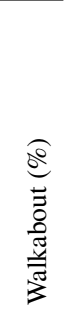 \\
\hline Fan & 2009 & China & 312 & 3.53 & 45.8 & 54.5 & - & - & - & 9.1 & 9.1 & 18.2 & 9.1 & - \\
\hline Kenangil & 2010 & Turkey & 554 & 5.9 & - & 42.0 & 57.0 & - & 24.0 & 12.1 & 27.0 & 21.0 & - & - \\
\hline Poletti & 2013 & Italy & 805 & 8.1 & 49.8 & 36.9 & 3.1 & - & 12.3 & 40.0 & 29.2 & 3.1 & - & - \\
\hline Weintraub & 2010 & USA & 3090 & 13.6 & 66 & 25.7 & - & - & 42.1 & 36.7 & 31.4 & - & - & - \\
\hline Callesen & 2014 & Denmark & 490 & 35.9 & - & 25.0 & 30.1 & 46.5 & 20.3 & 19.8 & 23.9 & 19.2 & - & 14.2 \\
\hline Valença & 2013 & Brazil & 152 & 18.4 & 25.6 & 64.3 & - & - & 57.1 & 7.1 & 42.9 & - & - & - \\
\hline Corvol & 2018 & France & 426 & 19.7 & 73.5 & 43.1 & - & - & 23.3 & 19.8 & 53.3 & - & - & - \\
\hline Perez-Lloret & 2012 & France & 203 & 25.0 & 79.3 & 39.8 & - & - & 23.9 & 11.9 & 55.7 & - & - & - \\
\hline $\begin{array}{l}\text { Rodriguez- } \\
\text { violante }\end{array}$ & 2014 & Mexico & 450 & 25.7 & 57.3 & 11.7 & $* 55.8$ & $* 55.8$ & 11.7 & 5.2 & 33.8 & - & - & - \\
\hline Ramirez Gomez & 2017 & $\begin{array}{l}\text { Argentina, Colombia, } \\
\text { Ecuador }\end{array}$ & 255 & 27.5 & 77.2 & 35.7 & 20.0 & 1.4 & 14.3 & 17.1 & 47.1 & - & - & - \\
\hline Joutsa & 2012 & Finland & 575 & 27.7 & 74.9 & 64.6 & 45.3 & 65.1 & 28.6 & 25.0 & 33.3 & & - & - \\
\hline Antonini & 2017 & Italy & 1095 & 29.1 & 78 & 34.0 & 14.1 & 44.8 & 22.6 & 18.6 & 34.6 & 16.7 & - & - \\
\hline Erga & 2017 & Norway & 125 & 30.4 & 62.4 & & 31.6 & 34.2 & & & & 7.9 & - & - \\
\hline Zhang & 2017 & China & 142 & 31.0 & 49.3 & 9.0 & 26.7 & 20.3 & 15.8 & 22.6 & 18.1 & 36.5 & - & - \\
\hline Garcia-Ruiz & 2014 & Spain & 233 & 39.1 & 100 & 30.8 & 31.9 & 49.5 & 17.6 & 9.9 & 6.6 & 7.7 & - & - \\
\hline Sharma & 2015 & India & 299 & 42.8 & 81.9 & 25.8 & 29.0 & 22.0 & 19.6 & 7.7 & 12.5 & 18.0 & - & - \\
\hline Kishore & 2013 & India & 305 & 31.5 & 49 & 16.0 & 50.0 & - & 26.0 & 14.6 & 25.0 & 10.4 & - & - \\
\hline Otmani $\mathrm{H}$ & 2019 & Morocco & 125 & 28.0 & - & 28.6 & $* 40.0$ & $* 40.0$ & 34.3 & 11.4 & 25.7 & 0.0 & - & - \\
\hline Giladi & 2007 & Israel & 193 & 14.0 & 59.6 & 63.0 & - & - & 22.2 & 22.2 & 25.9 & 0.0 & - & - \\
\hline Chiang & 2012 & Taiwan & 268 & 5.6 & - & 53.3 & - & - & & 26.7 & 6.7 & 13.3 & - & - \\
\hline Wang & 2016 & China & 217 & 4.2 & 46.5 & 44.4 & - & - & 11.1 & 33.3 & 11.1 & - & - & - \\
\hline Lee & 2009 & South Korea & 1167 & 10.1 & 72.8 & 28.0 & 41.5 & - & 24.6 & 12.7 & 33.9 & - & - & - \\
\hline
\end{tabular}

*refers to a study which has counted hobbyism and punding as the same sub-type of ICB. Percentages represent No. of patients with that particular ICB divided by total number of patients with ICB. ICB, impulse control behaviour; DA, dopamine agonist; DDS, dopamine dysregulation syndrome. Where data was not reported/recorded in the articles they have been replaced with a dash.

\section{CONTRIBUTORS TO ETHNIC VARIATION IN PD}

\section{Biological}

\section{Genetic factors}

The commonest monogenic forms of PD are caused by mutations in genes such as $L R R K 2, P A R K 2$, $S N C A$ and DJ-1 [123]. They are associated with different phenotypes and their prevalence differs in different ethnic groups [124, 125]. For example, LRRK2 p.G2019S is the most common genetic cause of PD worldwide and accounts for $1 \%$ of sporadic PD and $4 \%$ of familial PD [126]. However the prevalence of LRRK2 p.G2019S is 30-39\% in North African Berbers with PD and 26\% in Ashkenazi Jewish PD cases, yet it seems to be completely absent in Nigerian PD patients [127-129].
Given their rarity, little is known about ethnic variation in the main recessive causes of PD such as parkin and $D J 1$, but a variant of PINK1 is known to have a higher carrier frequency in Filipinos [130]. It is important to note that spinocerebellar ataxia type 3 can present in Black patients with parkinsonism and levodopa responsiveness that can be clinically identical to idiopathic PD [131].

Variation in the GBA gene is associated with an increase in the risk of PD and a reduction in the age of onset of PD in patients who carry risk variants $[132,133]$. The prevalence and penetrance of $G B A$ mutations varies by ethnicity. For example, the $G B A$ variants 84 insGG and $\mathrm{R} 496 \mathrm{H}$ increase risk of $\mathrm{PD}$ exclusively in Ashkenazi Jewish populations [134].

Common genetic variants with small independent associations with PD are identified through genomewide association studies (GWAS). The largest PD 
GWAS (37,700 PD cases and 1.4 million controls) was recently conducted in PD patients of European ancestry [135]. Two GWASes have been conducted with Asian PD patients; the first in 2017 with 5,125 PD cases and 17,604 controls in Singapore, Hong Kong, Malaysia, Korea, mainland China and Taiwan [136]. A smaller PD GWAS was performed in Japan (2,011 PD cases and 18,381 controls) in 2009 [137]. We are not aware of any multi-ethnic GWAS and this is a priority area for further research [135]. Both the GWASes conducted in Asian patients found no association across the MAPT locus in contrast to the GWAS in a European population which found strong associations. European and Asian GWAS all found strong association signals in $L R R K 2, S N C A$ and MCCC1 loci [135-137].

There are many studies reporting ethnic variation in the genetics of PD [138] and it is beyond the scope of this review to fully explore ethnic variation in prevalence and penetrance in every mutation linked with parkinsonism. There have been no GWAS in African, South American, South Asian or Middle Eastern PD patients that we know of. Genetic variation almost certainly contributes substantially to the heterogeneity seen in the manifestations of PD but as with many chronic diseases, the current literature largely reflects study in populations of European ancestry [1].

\section{Vascular disease}

In general, African-Americans have greater cerebral vascular burden than White Americans [139, 140]. We also know that cerebral small vessel disease is associated with postural instability and gait disturbance phenotypes, freezing of gait and worse cognitive impairment [141, 142]. Separately, it has been shown that PD patients with more cardiovascular risk factors have a worse prognosis [143]. It therefore follows that ethnic variation in cerebral vascular disease is likely to be a determinant and also a confounder of PD phenotypes.

\section{Dementia-associated pathology}

Black and Hispanic patients with PD seem to be at higher risk of developing cognitive symptoms and frank dementia. The prevalence of Alzheimer's disease (AD) follows a similar pattern [144, 145] which suggests the possibility that the ethnic variation observed with respect to the prevalence of cognitive symptoms in PD is driven by mixed Alzheimer's and Lewy body pathology. African-Americans have been shown to have a higher frequency of the APOE $\varepsilon 4$ gene [146]. Carriers of the APOE $\varepsilon 4$ gene with PD have a faster rate of cognitive decline [147] supporting the notion of a mixed Alzheimer's and Parkinson's pathology driving some of the ethnic variation observed.

\section{Co-morbidities}

The effect of co-morbidities on risk and manifestations of PD is an important current topic in research. For example, type 2 diabetes mellitus (T2DM) has been shown to have an association with subsequent PD [148]. T2DM is very prevalent in Asia and South Asians are known to be at increased risk of T2DM which is partly determined by genetic factors in addition to diet and lifestyle [149]. The extent to which T2DM and other co-morbidities may be determining ethnic variation observed in PD is unknown at present but an important topic to further explore.

\section{Non-biological}

\section{Healthcare inequalities}

Globally there are large inequalities in the diagnosis and treatment of PD. Generally, in low-middle income countries there is less access to PD medication and neurology services. In Sub-Saharan Africa there are very few neurologists and PD medications are unreliably supplied and expensive [150, 151]. Studies comparing European PD patients to African PD patients conclude that patients in Africa have more severe disease but, despite this, are taking lower doses of levodopa. PD patients in Africa are symptomatic for longer periods before levodopa initiation and are more likely to be treated with anti-cholinergics and amantadine, compared with European patients who are more likely to be prescribed dopamine agonists, levodopa, COMT inhibitors and MAO-B inhibitors [36, 152]. Another consideration is how geopolitical circumstances affect access to medication for chronic diseases, with countries such as Cuba in Central America, and Iran in the Middle East, likely struggling to supply essential PD drugs due to political sanctions.

Within a single country, there is good evidence that healthcare inequalities exist in the detection, diagnosis and treatment of PD. The only studies comparing national healthcare inequalities in PD have been conducted in the USA, a country with greater healthcare inequalities than many other countries in the world [153]. It is unknown whether the findings are applicable to other countries and it would be interesting to know whether the results reproduce in countries 
Table 4

Future directions to ameliorate ethnic inequalities in PD research

- Future cross-sectional and cohort studies in ethnically diverse samples of PD cases

- A drive to ensure future GWAS studies are as representative of the global population as possible

- Sharing of raw UPDRS data to enable meta-analysis of mono-ethnic studies

- Developing a standardised method of determining the motor sub-type

- Analysis of ethnic variation in cognitive impairment and neuropsychiatric features that are major determinants of morbidity and mortality in PD

- Establish culturally fair definitions of cognitive impairment

- Investigate role of vascular risk factors in ethnic variation in PD

- Exploration of the role that ethnic and geographic variation in comorbidities have as determinants of ethnic variation in PD

- Further assessment of the contribution of co-morbid Alzheimer's pathology in shaping ethnic variation seen in PD

- Improving awareness of ethnic healthcare inequalities in the diagnosis and treatment of PD and ameliorating them where possible

- Neuropathological studies in ethnically diverse PD cases

with universal healthcare systems. For other medical conditions, ethnic health inequalities exist even in countries such as the UK which have universal healthcare systems [154]. Black patients in the USA are less likely to be treated by a neurologist than White patients $[155,156]$. This may in-part explain some of the suspected under-ascertainment of PD in patients from certain ethnic backgrounds. For PD patients, being treated by a neurologist was inversely associated with residing in a nursing home, hip fractures and likelihood of death [155, 157]. Dahodwala et al., showed that African-Americans are four times less likely than White PD patients to receive PD treatment (OR 0.24; 95\% CI 0.09-0.64) [158]. This finding has been replicated [157, 159] and there is evidence the inequalities extend to the treatment of depression and advanced therapies in PD patients as well [160-162]. Amongst the minority ethnic patients that do receive treatment prescribing errors are more likely; Hispanic PD patients have an increased probability of being co-prescribed an anticholinesterase inhibitor and a high potency anticholinergic; a frank prescribing error [122]. To summarise, PD patients from minority ethnic backgrounds in the USA are less likely to be cared for by a neurologist, receive a diagnosis and be treated adequately for their PD.

One major limitation in the existing literature on ethnic variation of cognitive changes in PD is the definition of dementia using conventional neuropsychological instruments that are known to lack cultural fairness $[163,164]$. Future studies will need to consider this source of confounding in order to establish whether there are true biological differences in the incidence of cognitive decline in PD. Data on the relative prominence of neuropsychiatric features among ethnic groups is largely lacking, and will be important to study further given their strong association with morbidity and care burden [118], as well as their potential to reflect specific underlying patterns of neuropathological change [165].

\section{Under-reporting of symptoms}

Another factor which could affect ascertainment is the fact that African-Americans and ChineseAmericans are more likely to perceive PD symptoms as a normal part of aging than White-Americans [166]. This may explain findings showing that Black patients under-report their symptoms and could account for some differences in the severity of PD seen [167]. In a multi-ethnic study of PD knowledge in Asia, significant differences in PD knowledge according to ethnicity were found; people of Chinese ethnicity were more aware of the non-motor symptoms of PD compared to Malay people $(p<0.001)$ and Chinese people were more likely than Indians to be aware that not all patients with PD have a tremor $(p=0.009)$ [168].

\section{CONCLUSIONS}

It seems probable that there are geographic and ethnic differences in the clinical manifestations, epidemiology and mortality of PD. What is unclear is the exact nature of these differences and their cause. Black and Hispanic PD patients seem to be at increased risk of cognitive impairment but whether this is due to modifiable vascular risk factors, different rates of Alzheimer's pathology, genetic factors or healthcare inequalities is unknown. In Table 4 we have set out what we believe should be research goals in this field. Further prospective clinico-pathological studies in multi-ethnic populations and in Black and Asian populations in countries other than Europe and the USA are important research goals. 


\section{ACKNOWLEDGMENTS}

Dr Aaron Ben-Joseph - Dr Ben-Joseph is funded by the Virginia Keiley Benefaction grant.

Dr Charles Marshall - Dr Marshall is funded by the Barts Charity.

Professor Andrew Lees - Professor Lees funded by the Reta Lila Weston Institute of Neurological Studies, University College London, Institute of Neurology and reports consultancies from: Britannia Pharmaceuticals and BIAL Portela. He also reports grants and/or research support from the Frances and Renee Hock Fund, and honoraria from Britannia Pharmaceuticals, Profile Pharma, UCB, Roche, BIAL, STADA Nordic, Nordiclnfu Care, and NeuroDerm.

Dr Alastair Noyce - Dr. Noyce is funded by the Barts Charity. Dr. Noyce reports additional grants from Parkinson's UK, Virginia Kieley benefaction, grants and non-financial support from GE Healthcare, and personal fees from Profile, Roche, Biogen, BIAL and Britannia, outside the submitted work.

\section{CONFLICT OF INTEREST}

The authors have no conflict of interest to report.

\section{REFERENCES}

[1] Martin AR, Kanai M, Kamatani Y, Okada Y, Neale BM, Daly MJ (2019) Clinical use of current polygenic risk scores may exacerbate health disparities. Nat Genet 51, 584-591.

[2] Global, regional, and national burden of Parkinson's disease, 1990-2016: A systematic analysis for the Global Burden of Disease Study (2016). Lancet Neurol 17, 939953.

[3] Rossi A, Berger K, Chen H, Leslie D, Mailman RB, Huang X (2018) Projection of the prevalence of Parkinson's disease in the coming decades: Revisited. Mov Disord 33, 156-159.

[4] Thenganatt MA, Jankovic J (2014) Parkinson disease subtypes. JAMA Neurol 71, 499-504.

[5] Lawton M, Ben-Shlomo Y, May MT, Baig F, Barber TR, Klein JC, Swallow DMA, Malek N, Grosset KA, Bajaj N, Barker RA, Williams N, Burn DJ, Foltynie T, Morris HR, Wood NW, Grosset DG, Hu MTM (2018) Developing and validating Parkinson's disease subtypes and their motor and cognitive progression. J Neurol Neurosurg Psychiatry 89, $1279-1287$.

[6] Zhang X, Chou J, Liang J, Xiao C, Zhao Y, Sarva H, Henchcliffe C, Wang F (2019) Data-driven subtyping of Parkinson's disease using longitudinal clinical records: A cohort study. Sci Rep 9, 797.

[7] Mu J, Chaudhuri KR, Bielza C, de Pedro-Cuesta J, Larranaga P, Martinez-Martin P (2017) Parkinson's disease subtypes identified from cluster analysis of motor and non-motor symptoms. Front Aging Neurosci 9, 301.

[8] Sauerbier A, Jenner P, Todorova A, Chaudhuri KR (2016) Non motor subtypes and Parkinson's disease. Parkinsonism Relat Disord 22(Suppl 1), S41-46.

[9] Pagano G, Ferrara N, Brooks DJ, Pavese N (2016) Age at onset and Parkinson disease phenotype. Neurology 86, 1400-1407.

[10] De Pablo-Fernández E, Lees AJ, Holton JL, Warner TT (2019) Prognosis and neuropathologic correlation of clinical subtypes of Parkinson disease. JAMA Neurol 76, 470-479.

[11] Keener AM, Paul KC, Folle A, Bronstein JM, Ritz B (2018) Cognitive impairment and mortality in a population-based Parkinson's disease cohort. J Parkinsons Dis 8, 353-362.

[12] Burn DJ, Rowan EN, Allan LM, Molloy S, O'Brien JT, McKeith IG (2006) Motor subtype and cognitive decline in Parkinson's disease, Parkinson's disease with dementia, and dementia with Lewy bodies. J Neurol Neurosurg Psychiatry 77, 585-589.

[13] Zhang Y, Wang C, Wang Y, Xiao Q, Liu J, Ma J, Zhou H, Pan J, Tan Y, Chen S, Xu G, Wang G (2018) Mortality from Parkinson's disease in China: Findings from a ten-year follow up study in Shanghai. Parkinsonism Relat Disord 55, 75-80.

[14] Pringsheim T, Jette N, Frolkis A, Steeves TD (2014) The prevalence of Parkinson's disease: A systematic review and meta-analysis. Mov Disord 29, 1583-1590.

[15] Driver JA, Logroscino G, Gaziano JM, Kurth T (2009) Incidence and remaining lifetime risk of Parkinson disease in advanced age. Neurology 72, 432-438.

[16] Van Den Eeden SK, Tanner CM, Bernstein AL, Fross RD, Leimpeter A, Bloch DA, Nelson LM (2003) Incidence of Parkinson's disease: Variation by age, gender, and race/ethnicity. Am J Epidemiol 157, 1015-1022.

[17] Abbas MM, Xu Z, Tan LCS (2018) Epidemiology of Parkinson's disease-east versus west. Mov Disord Clin Pract 5, 14-28.

[18] Dotchin C, Msuya O, Kissima J, Massawe J, Mhina A, Moshy A, Aris E, Jusabani A, Whiting D, Masuki G, Walker R (2008) The prevalence of Parkinson's disease in rural Tanzania. Mov Disord 23, 1567-1672.

[19] Wright Willis A, Evanoff BA, Lian M, Criswell SR, Racette BA (2010) Geographic and ethnic variation in Parkinson disease: A population-based study of US Medicare beneficiaries. Neuroepidemiology 34, 143-151.

[20] Pitcher TL, Myall DJ, Pearson JF, Lacey CJ, DalrympleAlford JC, Anderson TJ, MacAskill MR (2018) Parkinson's disease across ethnicities: A nationwide study in New Zealand. Mov Disord 33, 1440-1448.

[21] Jendroska K, Olasode BJ, Daniel SE, Elliott L, Ogunniyi AO, Aghadiuno PU, Osuntokun BO, Lees AJ (1994) Incidental Lewy body disease in black Africans. Lancet 344, 882-883.

[22] Muthane UB, Chickabasaviah YT, Henderson J, Kingsbury AE, Kilford L, Shankar SK, Subbakrishna DK, Lees AJ (2006) Melanized nigral neuronal numbers in Nigerian and British individuals. Mov Disord 21, 1239-1241.

[23] Willis AW, Schootman M, Kung N, Evanoff BA, Perlmutter JS, Racette BA (2012) Predictors of survival in patients with Parkinson disease. Arch Neurol 69, 601-607.

[24] Fernandes GC, Socal MP, Schuh AF, Rieder CR (2015) Clinical and epidemiological factors associated with 
mortality in Parkinson's disease in a Brazilian cohort. Parkinsons Dis 2015, 959304.

[25] Mayeux R, Marder K, Cote LJ, Denaro J, Hemenegildo N, Mejia H, Tang MX, Lantigua R, Wilder D, Gurland B, Hauser A (1995) The frequency of idiopathic Parkinson's disease by age, ethnic group, and sex in northern Manhattan, 1988-1993. Am J Epidemiol 142, 820-827.

[26] Djaldetti R, Hassin-Baer S, Farrer MJ, Vilarino-Guell C, Ross OA, Kolianov V, Yust-Katz S, Treves TA, Barhum Y, Hulihan M, Melamed E (2008) Clinical characteristics of Parkinson's disease among Jewish Ethnic groups in Israel. J Neural Transm (Vienna) 115, 1279-1284.

[27] Harris-Hayes M, Willis AW, Klein SE, Czuppon S, Crowner B, Racette BA (2014) Relative mortality in U.S. Medicare beneficiaries with Parkinson disease and hip and pelvic fractures. J Bone Joint Surg Am 96, e27.

[28] Lo RY, Tanner CM, Albers KB, Leimpeter AD, Fross RD, Bernstein AL, McGuire V, Quesenberry CP, Nelson LM, Van Den Eeden SK (2009) Clinical features in early Parkinson disease and survival. Arch Neurol 66, 13531358.

[29] Fernandez HH, Lapane KL (2002) Predictors of mortality among nursing home residents with a diagnosis of Parkinson's disease. Med Sci Monit 8, Cr241-246.

[30] Mayeda ER, Glymour MM, Quesenberry CP, Johnson JK, Perez-Stable EJ, Whitmer RA (2017) Survival after dementia diagnosis in five racial/ethnic groups. Alzheimers Dement 13, 761-769.

[31] Caparros-Lefebvre D, Sergeant N, Lees A, Camuzat A, Daniel S, Lannuzel A, Brice A, Tolosa E, Delacourte A, Duyckaerts C (2002) Guadeloupean parkinsonism: A cluster of progressive supranuclear palsy-like tauopathy. Brain 125, 801-811.

[32] Caparros-Lefebvre D, Lees AJ (2005) Atypical unclassifiable parkinsonism on Guadeloupe: An environmental toxic hypothesis. Mov Disord 20(Suppl 12), S114-118

[33] Lehericy S, Hartmann A, Lannuzel A, Galanaud D, Delmaire C, Bienaimee MJ, Jodoin N, Roze E, Gaymard B, Vidailhet M (2010) Magnetic resonance imaging lesion pattern in Guadeloupean parkinsonism is distinct from progressive supranuclear palsy. Brain 133, 2410-2425.

[34] Chaudhuri KR, Hu MT, Brooks DJ (2000) Atypical parkinsonism in Afro-Caribbean and Indian origin immigrants to the UK. Mov Disord 15, 18-23.

[35] Yu R-L, Wu R-M, Chan AYY, Mok V, Wu Y-R, Tilley BC, Luo S, Wang L, LaPelle NR, Stebbins GT, Goetz CG (2016) Cross-cultural differences of the non-motor symptoms studied by the traditional Chinese version of the International Parkinson and Movement Disorder SocietyUnified Parkinson's Disease Rating Scale. Mov Disord Clin Pract 4, 68-77.

[36] Cilia R, Akpalu A, Sarfo FS, Cham M, Amboni M, Cereda E, Fabbri M, Adjei P, Akassi J, Bonetti A, Pezzoli G (2014) The modern pre-levodopa era of Parkinson's disease: Insights into motor complications from sub-Saharan Africa. Brain 137, 2731-2742.

[37] Appleman ER, Stavitsky K, Cronin-Golomb A (2011) Relation of subjective quality of life to motor symptom profile in Parkinson's disease. Parkinsons Dis 2011, 472830.

[38] Ramani L, Malek N, Patterson J, Nissen T, Newman EJ (2017) Relationship between [(123) I]-FP-CIT SPECT and clinical progression in Parkinson's disease. Acta Neurol Scand 135, 400-406.
[39] Choi SM, Kim BC, Cho BH, Kang KW, Choi KH, Kim JT, Lee SH, Park MS, Kim MK, Cho KH (2018) Comparison of two motor subtype classifications in de novo Parkinson's disease. Parkinsonism Relat Disord 54, 74-78.

[40] Moccia M, Tedeschi E, Ugga L, Erro R, Picillo M, Caranci F, Barone P, Brunetti A (2016) White matter changes and the development of motor phenotypes in de novo Parkinson's disease. J Neurol Sci 367, 215-219.

[41] Alves G, Larsen JP, Emre M, Wentzel-Larsen T, Aarsland D (2006) Changes in motor subtype and risk for incident dementia in Parkinson's disease. Mov Disord 21, 11231130 .

[42] Muller B, Larsen JP, Wentzel-Larsen T, Skeie GO, Tysnes OB (2011) Autonomic and sensory symptoms and signs in incident, untreated Parkinson's disease: Frequent but mild. Mov Disord 26, 65-72.

[43] Yuan YS, Zhou XJ, Tong Q, Zhang L, Zhang L, Qi ZQ, Ge S, Zhang KZ (2013) Change in plasma levels of amino acid neurotransmitters and its correlation with clinical heterogeneity in early Parkinson's disease patients. CNS Neurosci Ther 19, 889-896.

[44] Poletti M, Frosini D, Pagni C, Lucetti C, Del Dotto P, Tognoni G, Ceravolo R, Bonuccelli U (2011) The association between motor subtypes and alexithymia in de novo Parkinson's disease. J Neurol 258, 1042-1045.

[45] Reinoso G, Allen JC Jr, Au WL, Seah SH, Tay KY, Tan LC (2015) Clinical evolution of Parkinson's disease and prognostic factors affecting motor progression: 9-year follow-up study. Eur J Neurol 22, 457-463.

[46] Konno T, Deutschlander A, Heckman MG, Ossi M, Vargas ER, Strongosky AJ, van Gerpen JA, Uitti RJ, Ross OA, Wszolek ZK (2018) Comparison of clinical features among Parkinson's disease subtypes: A large retrospective study in a single center. $J$ Neurol Sci 386, 39-45.

[47] Nicoletti A, Mostile G, Nicoletti G, Arabia G, Iliceto G, Lamberti P, Marconi R, Morgante L, Barone P, Quattrone A, Zappia M (2016) Clinical phenotype and risk of levodopa-induced dyskinesia in Parkinson's disease. J Neurol 263, 888-894.

[48] Moretti R, Torre P, Antonello RM, Rosin MV, Esposito F, Furman MR, Bellini G (2012) Apathy: A complex symptom specific to the clinical pattern of presentation of Parkinson's disease? Am J Alzheimers Dis Other Demen 27, 196-201.

[49] Rajput AH, Rajput ML, Ferguson LW, Rajput A (2017) Baseline motor findings and Parkinson disease prognostic subtypes. Neurology 89, 138-143.

[50] Auyeung M, Tsoi TH, Mok V, Cheung CM, Lee CN, Li $R$, Yeung E (2012) Ten year survival and outcomes in a prospective cohort of new onset Chinese Parkinson's disease patients. J Neurol Neurosurg Psychiatry 83, 607611.

[51] Hiorth YH, Lode K, Larsen JP (2013) Frequencies of falls and associated features at different stages of Parkinson's disease. Eur J Neurol 20, 160-166.

[52] Aygun D, Turkel Y, Onar MK, Sunter T (2014) Clinical REM sleep behavior disorder and motor subtypes in Parkinson's disease: A questionnaire-based study. Clin Neurol Neurosurg 119, 54-58.

[53] Kim KJ, Bae YJ, Kim J-M, Kim BJ, Oh ES, Yun JY, Kim JS, Kim H-J (2018) The prevalence of cerebral microbleeds in non-demented Parkinson's disease patients. J Korean Med Sci 33, e289. 
[54] Huang X, Ng SY, Chia NS, Setiawan F, Tay KY, Au WL, Tan EK, Tan LC (2019) Non-motor symptoms in early Parkinson's disease with different motor subtypes and their associations with quality of life. Eur J Neurol 26, 400-406.

[55] Suzuki K, Okuma Y, Uchiyama T, Miyamoto M, Sakakibara R, Shimo Y, Hattori N, Kuwabara S, Yamamoto T, Kaji Y, Hirano S, Kadowaki T, Hirata K (2017) Impact of sleep-related symptoms on clinical motor subtypes and disability in Parkinson's disease: A multicentre cross-sectional study. J Neurol Neurosurg Psychiatry 88, 953-959.

[56] Huertas I, Jesús S, Lojo JA, García-Gómez FJ, CáceresRedondo MT, Oropesa-Ruiz JM, Carrillo F, VargasGonzalez L, Martín Rodríguez JF, Gómez-Garre P, García-Solís D, Mir P (2017) Lower levels of uric acid and striatal dopamine in non-tremor dominant Parkinson's disease subtype. PloS One 12, e174644.

[57] Herb JN, Rane S, Isaacs DA, Van Wouwe N, Roman OC, Landman BA, Dawant BM, Hedera P, Zald DH, Neimat JS, Wylie SA, Donahue MJ, Claassen DO (2016) Cortical implications of advancing age and disease duration in Parkinson's disease patients with postural instability and gait dysfunction. J Parkinsons Dis 6, 441-451.

[58] Johnson AR, Bucks RS, Kane RT, Thomas MG, Gasson N, Loftus AM (2016) Motor subtype as a predictor of future working memory performance in idiopathic Parkinson's disease. PLoS One 11, e0152534.

[59] Ba F, Obaid M, Wieler M, Camicioli R, Martin WR (2016) Parkinson disease: The relationship between non-motor symptoms and motor phenotype. Can J Neurol Sci 43, 261-267.

[60] Deng X, Xiao B, Li HH, Lo YL, Chew LM, Prakash KM, Tan EK (2015) Sexual dysfunction is associated with postural instability gait difficulty subtype of Parkinson's disease. J Neurol 262, 2433-2439.

[61] Altinayar S, Oner S, Can S, Kizilay A, Kamisli S, Sarac K (2014) Olfactory disfunction and its relation olfactory bulb volume in Parkinson's disease. Eur Rev Med Pharmacol Sci 18, 3659-3664.

[62] Herman T, Weiss A, Brozgol M, Wilf-Yarkoni A, Giladi N, Hausdorff JM (2015) Cognitive function and other nonmotor features in non-demented Parkinson's disease motor subtypes. J Neural Transm (Vienna) 122, 1115-1124.

[63] Bordelon YM, Hays RD, Vassar SD, Diaz N, Bronstein J, Vickrey BG (2011) Medication responsiveness of motor symptoms in a population-based study of Parkinson disease. Parkinsons Dis 2011, 967839.

[64] van der Hoek TC, Bus BA, Matui P, van der Marck MA, Esselink RA, Tendolkar I (2011) Prevalence of depression in Parkinson's disease: Effects of disease stage, motor subtype and gender. J Neurol Sci 310, 220-224.

[65] Bohnen NI, Muller ML, Zarzhevsky N, Koeppe RA, Bogan CW, Kilbourn MR, Frey KA, Albin RL (2011) Leucoaraiosis, nigrostriatal denervation and motor symptoms in Parkinson's disease. Brain 134, 2358-2365.

[66] Iijima M, Kobayakawa T, Saito S, Osawa M, Tsutsumi Y, Hashimoto S, Uchiyama S (2011) Differences in odor identification among clinical subtypes of Parkinson's disease. Eur J Neurol 18, 425-429.

[67] Okubadejo NU, Ojo OO, Oshinaike OO (2010) Clinical profile of parkinsonism and Parkinson's disease in Lagos, Southwestern Nigeria. BMC Neurol 10, 1.

[68] Kang GA, Bronstein JM, Masterman DL, Redelings M, Crum JA, Ritz B (2005) Clinical characteristics in early
Parkinson's disease in a central California populationbased study. Mov Disord 20, 1133-1142.

[69] Amod FH, Bhigjee AI (2019) Clinical series of Parkinson's disease in KwaZulu-Natal, South Africa: Retrospective chart review. J Neurol Sci 401, 62-65.

[70] Woitalla D, Mueller T, Russ H, Hock K, Haeger DA (2007) The management approaches to dyskinesia vary from country to country. Neuroepidemiology 29, 163-169.

[71] Seppi K, Ray Chaudhuri K, Coelho M, Fox SH, Katzenschlager R, Perez Lloret S, Weintraub D, Sampaio C (2019) Update on treatments for nonmotor symptoms of Parkinson's disease-an evidence-based medicine review. Mov Disord 34, 180-198.

[72] Chaudhuri KR, Martinez-Martin P, Schapira AH, Stocchi F, Sethi K, Odin P, Brown RG, Koller W, Barone P, MacPhee G, Kelly L, Rabey M, MacMahon D, Thomas S, Ondo W, Rye D, Forbes A, Tluk S, Dhawan V, Bowron A, Williams AJ, Olanow CW (2006) International multicenter pilot study of the first comprehensive self-completed nonmotor symptoms questionnaire for Parkinson's disease: The NMSQuest study. Mov Disord 21, 916-923.

[73] Li HJ, Zhang MF, Chen MX, Hu AL, Li JB, Zhang B, Liu W (2015) Validation of the nonmotor symptoms questionnaire for Parkinson's disease: Results from a Chinese pilot study. Int J Neurosci 125, 929-935.

[74] Khedr EM, El Fetoh NA, Khalifa H, Ahmed MA, El Beh KM (2013) Prevalence of non motor features in a cohort of Parkinson's disease patients. Clin Neurol Neurosurg 115, 673-677.

[75] Bostantjopoulou S, Katsarou Z, Karakasis C, Peitsidou E, Milioni D, Rossopoulos N (2013) Evaluation of non-motor symptoms in Parkinson's disease: An underestimated necessity. Hippokratia 17, 214-219.

[76] Martinez-Martin P, Schapira AH, Stocchi F, Sethi K, Odin P, MacPhee G, Brown RG, Naidu Y, Clayton L, Abe K, Tsuboi Y, MacMahon D, Barone P, Rabey M, Bonuccelli U, Forbes A, Breen K, Tluk S, Olanow CW, Thomas S, Rye D, Hand A, Williams AJ, Ondo W, Chaudhuri KR (2007) Prevalence of nonmotor symptoms in Parkinson's disease in an international setting; study using nonmotor symptoms questionnaire in 545 patients. Mov Disord 22, 1623-1629.

[77] Rodriguez-Violante M, Cervantes-Arriaga A, VillarVelarde A, Corona T (2011) Relationship between the type and side of motor symptoms with the prevalence of nonmotor symptoms in Parkinson's disease. Neurologia 26, 319-324.

[78] Mukhtar S, Imran R, Zaheer M, Tariq H (2018) Frequency of non-motor symptoms in Parkinson's disease presenting to tertiary care centre in Pakistan: An observational, crosssectional study. BMJ Open 8, e019172.

[79] Tanveer K, Attique I, Sadiq W, Ahmad A (2018) Nonmotor symptoms in patients with Parkinson's disease: A cross-sectional survey. Cureus 10, e3412.

[80] Cosentino C, Nuñez Y, Torres L (2013) Frequency of nonmotor symptoms in Peruvian patients with Parkinson's disease. Arq Neuropsiquiatr 71, 216-219.

[81] Cheon SM, Ha MS, Park MJ, Kim JW (2008) Nonmotor symptoms of Parkinson's disease: Prevalence and awareness of patients and families. Parkinsonism Relat Disord 14, 286-290.

[82] Duncan GW, Khoo TK, Yarnall AJ, O'Brien JT, Coleman SY, Brooks DJ, Barker RA, Burn DJ (2014) Health-related quality of life in early Parkinson's disease: The impact of nonmotor symptoms. Mov Disord 29, 195-202. 
[83] Chaudhuri KR, Prieto-Jurcynska C, Naidu Y, Mitra T, Frades-Payo B, Tluk S, Ruessmann A, Odin P, Macphee G, Stocchi F, Ondo W, Sethi K, Schapira AH, Martinez Castrillo JC, Martinez-Martin P (2010) The nondeclaration of nonmotor symptoms of Parkinson's disease to health care professionals: An international study using the nonmotor symptoms questionnaire. Mov Disord 25, 704-709.

[84] Romenets SR, Wolfson C, Galatas C, Pelletier A, Altman R, Wadup L, Postuma RB (2012) Validation of the non-motor symptoms questionnaire (NMS-Quest). Parkinsonism Relat Disord 18, 54-58.

[85] Rana AQ, Qureshi AR, Fareez F, Rana MA (2016) Impact of ethnicity on mood disorders in Parkinson's disease. Int J Neurosci 126, 734-738.

[86] Lin YY, Chen RS, Lu CS, Huang YZ, Weng YH, Yeh TH, Lin WY, Hung J (2017) Sleep disturbances in Taiwanese patients with Parkinson's disease. Brain Behav 7, e00806.

[87] Setthawatcharawanich S, Limapichat K, Sathirapanya P, Phabphal K (2014) Excessive daytime sleepiness and nighttime sleep quality in Thai patients with Parkinson's disease. J Med Assoc Thai 97, 1022-1027.

[88] Yu R-L, Tan C-H, Wu R-M (2015) The impact of nocturnal disturbances on daily quality of life in patients with Parkinson's disease. Neuropsychiatr Dis Treat 11, 20052012.

[89] Tan EK, Lum SY, Fook-Chong SM, Teoh ML, Yih Y, Tan L, Tan A, Wong MC (2002) Evaluation of somnolence in Parkinson's disease: Comparison with age- and sexmatched controls. Neurology 58, 465-468.

[90] Brodsky MA, Godbold J, Roth T, Olanow CW (2003) Sleepiness in Parkinson's disease: A controlled study. Mov Disord 18, 668-672.

[91] Hobson DE, Lang AE, Martin WR, Razmy A, Rivest J, Fleming J (2002) Excessive daytime sleepiness and sudden-onset sleep in Parkinson disease: A survey by the Canadian Movement Disorders Group. JAMA 287, 455463.

[92] Louter M, Munneke M, Bloem BR, Overeem S (2012) Nocturnal hypokinesia and sleep quality in Parkinson's disease. J Am Geriatr Soc 60, 1104-1108.

[93] Poryazova R, Benninger D, Waldvogel D, Bassetti CL (2010) Excessive daytime sleepiness in Parkinson's disease: Characteristics and determinants. Eur Neurol 63, 129-135.

[94] Ratti PL, Negre-Pages L, Perez-Lloret S, Manni R, Damier P, Tison F, Destee A, Rascol O (2015) Subjective sleep dysfunction and insomnia symptoms in Parkinson's disease: Insights from a cross-sectional evaluation of the French CoPark cohort. Parkinsonism Relat Disord 21, 1323-1329.

[95] Zhu K, van Hilten JJ, Marinus J (2016) Course and risk factors for excessive daytime sleepiness in Parkinson's disease. Parkinsonism Relat Disord 24, 34-40.

[96] Weintraub D, Koester J, Potenza MN, Siderowf AD, Stacy M, Voon V, Whetteckey J, Wunderlich GR, Lang AE (2010) Impulse control disorders in Parkinson disease: A cross-sectional study of 3090 patients. Arch Neurol 67, 589-595.

[97] Corvol JC, Artaud F, Cormier-Dequaire F, Rascol O, Durif F, Derkinderen P, Marques AR, Bourdain F, Brandel JP, Pico F, Lacomblez L, Bonnet C, Brefel-Courbon C, OryMagne F, Grabli D, Klebe S, Mangone G, You H, Mesnage V, Lee PC, Brice A, Vidailhet M, Elbaz A (2018) Longitudinal analysis of impulse control disorders in Parkinson disease. Neurology 91, e189-e201.
[98] Perez-Lloret S, Rey MV, Fabre N, Ory F, Spampinato $\mathrm{U}$, Brefel-Courbon $\mathrm{C}$, Montastruc JL, Rascol O (2012) Prevalence and pharmacological factors associated with impulse-control disorder symptoms in patients with Parkinson disease. Clin Neuropharmacol 35, 261-265.

[99] Callesen MB, Weintraub D, Damholdt MF, Moller A (2014) Impulsive and compulsive behaviors among Danish patients with Parkinson's disease: Prevalence, depression, and personality. Parkinsonism Relat Disord 20, 22-26.

[100] Erga AH, Alves G, Larsen JP, Tysnes OB, Pedersen KF (2017) Impulsive and compulsive behaviors in Parkinson's disease: The Norwegian ParkWest Study. J Parkinsons Dis 7, 183-191.

[101] Sharma A, Goyal V, Behari M, Srivastva A, Shukla G, Vibha D (2015) Impulse control disorders and related behaviours (ICD-RBs) in Parkinson's disease patients: Assessment using "Questionnaire for impulsivecompulsive disorders in Parkinson's disease" (QUIP). Ann Indian Acad Neurol 18, 49-59.

[102] Sarathchandran P, Soman S, Sarma G, Krishnan S, Kishore A (2013) Impulse control disorders and related behaviors in Indian patients with Parkinson's disease. Mov Disord 28, 1901-1902.

[103] El Otmani H, Mouni FZ, Abdulhakeem Z, Attar Z, Rashad L, Saali I, El Moutawakil B, Rafai MA, Slassi I, Nadifi S (2019) Impulse control disorders in Parkinson disease: A cross-sectional study in Morocco. Rev Neurol (Paris) 175, 233-237.

[104] Fan W, Ding H, Ma J, Chan P (2009) Impulse control disorders in Parkinson's disease in a Chinese population. Neurosci Lett 465, 6-9.

[105] Kenangil G, Ozekmekci S, Sohtaoglu M, Erginoz E (2010) Compulsive behaviors in patients with Parkinson's disease. Neurologist 16, 192-195.

[106] Poletti M, Logi C, Lucetti C, Del Dotto P, Baldacci F, Vergallo A, Ulivi M, Del Sarto S, Rossi G, Ceravolo R, Bonuccelli U (2013) A single-center, cross-sectional prevalence study of impulse control disorders in Parkinson disease: Association with dopaminergic drugs. J Clin Psychopharmacol 33, 691-694.

[107] Valenca GT, Glass PG, Negreiros NN, Duarte MB, Ventura LM, Mueller M, Oliveira-Filho J (2013) Past smoking and current dopamine agonist use show an independent and dose-dependent association with impulse control disorders in Parkinson's disease. Parkinsonism Relat Disord 19, 698-700.

[108] Rodriguez-Violante M, Gonzalez-Latapi P, CervantesArriaga A, Camacho-Ordonez A, Weintraub D (2014) Impulse control and related disorders in Mexican Parkinson's disease patients. Parkinsonism Relat Disord 20, 907-910.

[109] Ramirez Gomez CC, Serrano Duenas M, Bernal O, Araoz N, Saenz Farret M, Aldinio V, Montilla V, Micheli F (2017) A multicenter comparative study of impulse control disorder in Latin American patients with Parkinson disease. Clin Neuropharmacol 40, 51-55.

[110] Joutsa J, Martikainen K, Vahlberg T, Voon V, Kaasinen V (2012) Impulse control disorders and depression in Finnish patients with Parkinson's disease. Parkinsonism Relat Disord 18, 155-160.

[111] Antonini A, Barone P, Bonuccelli U, Annoni K, Asgharnejad M, Stanzione P (2017) ICARUS study: Prevalence and clinical features of impulse control disorders in Parkinson's disease. J Neurol Neurosurg Psychiatry 88, 317-324. 
[112] Zhang Y, He AQ, Li L, Chen W, Liu ZG (2017) Clinical characteristics of impulse control and related disorders in Chinese Parkinson's disease patients. BMC Neurol 17, 98.

[113] Garcia-Ruiz PJ, Martinez Castrillo JC, Alonso-Canovas A, Herranz Barcenas A, Vela L, Sanchez Alonso P, Mata M, Olmedilla Gonzalez N, Mahillo Fernandez I (2014) Impulse control disorder in patients with Parkinson's disease under dopamine agonist therapy: A multicentre study. J Neurol Neurosurg Psychiatry 85, 840-844.

[114] Giladi N, Weitzman N, Schreiber S, Shabtai H, Peretz C (2007) New onset heightened interest or drive for gambling, shopping, eating or sexual activity in patients with Parkinson's disease: The role of dopamine agonist treatment and age at motor symptoms onset. J Psychopharmacol 21, 501-506.

[115] Wang X-P, Wei M, Xiao Q (2016) A survey of impulse control disorders in Parkinson's disease patients in Shanghai area and literature review. Transl Neurodegener 5, 4.

[116] Chiang HL, Huang YS, Chen ST, Wu YR (2012) Are there ethnic differences in impulsive/compulsive behaviors in Parkinson's disease? Eur J Neurol 19, 494-500.

[117] Goldman JG, Vernaleo BA, Camicioli R, Dahodwala N, Dobkin RD, Ellis T, Galvin JE, Marras C, Edwards J, Fields J, Golden R, Karlawish J, Levin B, Shulman L, Smith G, Tangney C, Thomas CA, Tröster AI, Uc EY, Coyan N, Ellman C, Ellman M, Hoffman C, Hoffman S, Simmonds D (2018) Cognitive impairment in Parkinson's disease: A report from a multidisciplinary symposium on unmet needs and future directions to maintain cognitive health. NPJ Parkinsons Dis 4, 19.

[118] Aarsland D, Marsh L, Schrag A (2009) Neuropsychiatric symptoms in Parkinson's disease. Mov Disord 24, 2175 2186.

[119] Backstrom D, Granasen G, Domellof ME, Linder J, Jakobson Mo S, Riklund K, Zetterberg H, Blennow K, Forsgren L (2018) Early predictors of mortality in parkinsonism and Parkinson disease: A population-based study. Neurology 91, e2045-e2056.

[120] Macleod AD, Taylor KS, Counsell CE (2014) Mortality in Parkinson's disease: A systematic review and metaanalysis. Mov Disord 29, 1615-1622.

[121] Levy G, Tang MX, Louis ED, Cote LJ, Alfaro B, Mejia H, Stern Y, Marder K (2002) The association of incident dementia with mortality in PD. Neurology 59, 1708-1713.

[122] Mantri S, Fullard M, Gray SL, Weintraub D, Hubbard RA, Hennessy S, Willis AW (2019) Patterns of dementia treatment and frank prescribing errors in older adults with Parkinson disease. JAMA Neurol 76, 41-49.

[123] Reed X, Bandres-Ciga S, Blauwendraat C, Cookson MR (2019) The role of monogenic genes in idiopathic Parkinson's disease. Neurobiol Dis 124, 230-239.

[124] Trinh J, Zeldenrust FMJ, Huang J, Kasten M, Schaake S, Petkovic S, Madoev H, Grunewald A, Almuammar S, Konig IR, Lill CM, Lohmann K, Klein C, Marras C (2018) Genotype-phenotype relations for the Parkinson's disease genes SNCA, LRRK2, VPS35: MDSGene systematic review. Mov Disord 33, 1857-1870.

[125] Shu L, Zhang Y, Sun Q, Pan H, Tang B (2019) A comprehensive analysis of population differences in LRRK2 variant distribution in Parkinson's disease. Front Aging Neurosci 11, 13.

[126] Healy DG, Falchi M, O'Sullivan SS, Bonifati V, Durr A, Bressman S, Brice A, Aasly J, Zabetian CP, Goldwurm S, Ferreira JJ, Tolosa E, Kay DM, Klein C, Williams DR,
Marras C, Lang AE, Wszolek ZK, Berciano J, Schapira AH, Lynch T, Bhatia KP, Gasser T, Lees AJ, Wood NW (2008) Phenotype, genotype, and worldwide genetic penetrance of LRRK2-associated Parkinson's disease: A case-control study. Lancet Neurol 7, 583-590.

[127] Benamer HT, de Silva R (2010) LRRK2 G2019S in the North African population: A review. Eur Neurol 63, 321325.

[128] Okubadejo NU, Rizig M, Ojo OO, Jonvik H, Oshinaike O, Brown E, Houlden H (2018) Leucine rich repeat kinase 2 (LRRK2) GLY2019SER mutation is absent in a second cohort of Nigerian Africans with Parkinson disease. PLoS One 13, e0207984.

[129] Orr-Urtreger A, Shifrin C, Rozovski U, Rosner S, Bercovich D, Gurevich T, Yagev-More H, Bar-Shira A, Giladi N (2007) The LRRK2 G2019S mutation in Ashkenazi Jews with Parkinson disease: Is there a gender effect? Neurology 69, 1595-1602.

[130] Rogaeva E, Johnson J, Lang AE, Gulick C, Gwinn-Hardy K, Kawarai T, Sato C, Morgan A, Werner J, Nussbaum R, Petit A, Okun MS, McInerney A, Mandel R, Groen JL, Fernandez HH, Postuma R, Foote KD, Salehi-Rad S, Liang Y, Reimsnider S, Tandon A, Hardy J, St George-Hyslop P, Singleton AB (2004) Analysis of the PINK1 gene in a large cohort of cases with Parkinson disease. Arch Neurol 61, 1898-904.

[131] Subramony SH, Hernandez D, Adam A, Smith-Jefferson S, Hussey J, Gwinn-Hardy K, Lynch T, McDaniel O, Hardy J, Farrer M, Singleton A (2002) Ethnic differences in the expression of neurodegenerative disease: MachadoJoseph disease in Africans and Caucasians. Mov Disord 17, 1068-1071.

[132] Sidransky E, Nalls MA, Aasly JO, Aharon-Peretz J, Annesi G, Barbosa ER, Bar-Shira A, Berg D, Bras J, Brice A, Chen CM, Clark LN, Condroyer C, De Marco EV, Durr A, Eblan MJ, Fahn S, Farrer MJ, Fung HC, GanOr Z, Gasser T, Gershoni-Baruch R, Giladi N, Griffith A, Gurevich T, Januario C, Kropp P, Lang AE, Lee-Chen GJ, Lesage S, Marder K, Mata IF, Mirelman A, Mitsui J, Mizuta I, Nicoletti G, Oliveira C, Ottman R, Orr-Urtreger A, Pereira LV, Quattrone A, Rogaeva E, Rolfs A, Rosenbaum H, Rozenberg R, Samii A, Samaddar T, Schulte C, Sharma M, Singleton A, Spitz M, Tan EK, Tayebi N, Toda T, Troiano AR, Tsuji S, Wittstock M, Wolfsberg TG, Wu YR, Zabetian CP, Zhao Y, Ziegler SG (2009) Multicenter analysis of glucocerebrosidase mutations in Parkinson's disease. $N$ Engl J Med 361, 1651-1661.

[133] Gan-Or Z, Amshalom I, Kilarski LL, Bar-Shira A, GanaWeisz M, Mirelman A, Marder K, Bressman S, Giladi N, Orr-Urtreger A (2015) Differential effects of severe vs mild GBA mutations on Parkinson disease. Neurology 84, 880-887.

[134] Zhang Y, Shu L, Sun Q, Zhou X, Pan H, Guo J, Tang B (2018) Integrated genetic analysis of racial differences of common GBA variants in Parkinson's disease: A metaanalysis. Front Mol Neurosci 11, 43.

[135] Nalls MA, Blauwendraat C, Vallerga CL, Heilbron K, Bandres-Ciga S, Chang D, Tan M, Kia DA, Noyce AJ, Xue A, Bras J, Young E, von Coelln R, SimónSánchez J, Schulte C, Sharma M, Krohn L, Pihlstrom L, Siitonen A, Iwaki H, Leonard H, Faghri F, Raphael Gibbs J, Hernandez DG, Scholz SW, Botia JA, Martinez M, Corvol J-C, Lesage S, Jankovic J, Shulman LM, Tienari P, Majamaa K, Toft M, Brice A, Yang J, Gan-Or Z, Gasser T, Heutink P, Shulman JM, Wood 
N, Hinds DA, Hardy J, Morris HR, Gratten J, Visscher PM, Graham RR, Singleton AB (2018) Parkinson's disease genetics: Identifying novel risk loci, providing causal insights and improving estimates of heritable risk. bioRxiv, 388165.

[136] Foo JN, Tan LC, Irwan ID, Au WL, Low HQ, Prakash KM, Ahmad-Annuar A, Bei J, Chan AY, Chen CM, Chen YC, Chung SJ, Deng H, Lim SY, Mok V, Pang H, Pei Z, Peng R, Shang HF, Song K, Tan AH, Wu YR, Aung T, Cheng CY, Chew FT, Chew SH, Chong SA, Ebstein RP, Lee J, Saw SM, Seow A, Subramaniam M, Tai ES, Vithana EN, Wong TY, Heng KK, Meah WY, Khor CC, Liu H, Zhang F, Liu J, Tan EK (2017) Genome-wide association study of Parkinson's disease in East Asians. Hum Mol Genet 26, 226-232.

[137] Satake W, Nakabayashi Y, Mizuta I, Hirota Y, Ito C, Kubo M, Kawaguchi T, Tsunoda T, Watanabe M, Takeda A, Tomiyama H, Nakashima $\mathrm{K}$, Hasegawa $\mathrm{K}$, Obata F, Yoshikawa T, Kawakami H, Sakoda S, Yamamoto M, Hattori N, Murata M, Nakamura Y, Toda T (2009) Genome-wide association study identifies common variants at four loci as genetic risk factors for Parkinson's disease. Nat Genet 41, 1303-1307.

[138] Guo Y, Tan T, Deng X, Song Z, Yang Z, Yang Y, Deng H (2015) TCEANC2 rs10788972 and rs 12046178 variants in the PARK10 region in Chinese Han patients with sporadic Parkinson's disease. Neurobiol Aging 36, 3335.e33313335.e3332.

[139] Gottesman RF, Fornage M, Knopman DS, Mosley TH (2015) Brain aging in African-Americans: The Atherosclerosis Risk in Communities (ARIC) experience. Curr Alzheimer Res 12, 607-613.

[140] Waldstein SR, Dore GA, Davatzikos C, Katzel LI, Gullapalli R, Seliger SL, Kouo T, Rosenberger WF, Erus G, Evans MK, Zonderman AB (2017) Differential associations of socioeconomic status with global brain volumes and white matter lesions in African American and white adults: The HANDLS SCAN Study. Psychosom Med 79, 327-335.

[141] Wan Y, Hu W, Gan J, Song L, Wu N, Chen Y, Liu Z (2019) Exploring the association between Cerebral small-vessel diseases and motor symptoms in Parkinson's disease. Brain Behav 9, e01219.

[142] Gallardo MJ, Cabello JP, Pastor C, Munoz-Torrero JJ, Carrasco S, Ibanez R, Vaamonde J (2014) Patients with advanced Parkinson's disease with and without freezing of gait: A comparative analysis of vascular lesions using brain MRI. Neurologia 29, 218-223.

[143] Mollenhauer B, Zimmermann J, Sixel-Doring F, Focke NK, Wicke T, Ebentheuer J, Schaumburg M, Lang E, Friede T, Trenkwalder C (2019) Baseline predictors for progression 4 years after Parkinson's disease diagnosis in the De Novo Parkinson Cohort (DeNoPa). Mov Disord 34, 67-77.

[144] Mehta KM, Yeo GW (2017) Systematic review of dementia prevalence and incidence in United States race/ethnic populations. Alzheimers Dement 13, 72-83.

[145] (2010) 2010 Alzheimer's disease facts and figures. Alzheimers Dement 6, 158-194.

[146] Logue MW, Schu M, Vardarajan BN, Buros J, Green RC, Go RC, Griffith P, Obisesan TO, Shatz R, Borenstein A, Cupples LA, Lunetta KL, Fallin MD, Baldwin CT, Farrer LA (2011) A comprehensive genetic association study of Alzheimer disease in African Americans. Arch Neurol 68, 1569-1579.
[147] Morley JF, Xie SX, Hurtig HI, Stern MB, Colcher A, Horn S, Dahodwala N, Duda JE, Weintraub D, Chen-Plotkin AS, Van Deerlin V, Falcone D, Siderowf A (2012) Genetic influences on cognitive decline in Parkinson's disease. Mov Disord 27, 512-518.

[148] De Pablo-Fernandez E, Goldacre R, Pakpoor J, Noyce AJ, Warner TT (2018) Association between diabetes and subsequent Parkinson disease: A record-linkage cohort study. Neurology 91, e139-e142.

[149] Zheng Y, Ley SH, Hu FB (2018) Global aetiology and epidemiology of type 2 diabetes mellitus and its complications. Nat Rev Endocrinol 14, 88-98.

[150] Dotchin C, Walker R (2012) The management of Parkinson's disease in sub-Saharan Africa. Expert Rev Neurother 12, 661-666.

[151] Williams U, Bandmann O, Walker R (2018) Parkinson's disease in Sub-Saharan Africa: A review of epidemiology, genetics and access to care. J Mov Disord 11, 53-64.

[152] Cubo E, Doumbe J, Martinez-Martin P, RodriguezBlazquez C, Kuate C, Mariscal N, Lopez I, Noubissi G, Mapoure YN, Jon JL, Mbahe S, Tchaleu B, Catalan MJ (2014) Comparison of the clinical profile of Parkinson's disease between Spanish and Cameroonian cohorts. J Neurol Sci 336, 122-126.

[153] Hero JO, Zaslavsky AM, Blendon RJ (2017) The United States leads other nations in differences by income in perceptions of health and health care. Health Affairs 36, 1032-1040.

[154] Evandrou M, Falkingham J, Feng Z, Vlachantoni A (2016) Ethnic inequalities in limiting health and self-reported health in later life revisited. $J$ Epidemiol Community Health 70, 653.

[155] Willis AW, Schootman M, Evanoff BA, Perlmutter JS, Racette BA (2011) Neurologist care in Parkinson disease: A utilization, outcomes, and survival study. Neurology 77, 851-857.

[156] Saadi A, Himmelstein DU, Woolhandler S, Mejia NI (2017) Racial disparities in neurologic health care access and utilization in the United States. Neurology 88, 22682275.

[157] Dahodwala N, Willis AW, Li P, Doshi JA (2017) Prevalence and correlates of anti-Parkinson drug use in a nationally representative sample. Mov Disord Clin Pract 4, 335-341.

[158] Dahodwala N, Xie M, Noll E, Siderowf A, Mandell DS (2009) Treatment disparities in Parkinson's disease. Ann Neurol 66, 142-145.

[159] Hemming JP, Gruber-Baldini AL, Anderson KE, Fishman PS, Reich SG, Weiner WJ, Shulman LM (2011) Racial and socioeconomic disparities in parkinsonism. Arch Neurol 68, 498-503.

[160] Cheng EM, Siderowf AD, Swarztrauber K, Lee M, Vassar S, Jacob E, Eisa MS, Vickrey BG (2008) Disparities of care in veterans with Parkinson's disease. Parkinsonism Relat Disord 14, 8-14.

[161] Chan AK, McGovern RA, Brown LT, Sheehy JP, Zacharia BE, Mikell CB, Bruce SS, Ford B, McKhann GM, 2nd (2014) Disparities in access to deep brain stimulation surgery for Parkinson disease: Interaction between African American race and Medicaid use. JAMA Neurol 71, 291299.

[162] Willis AW, Schootman M, Kung N, Wang XY, Perlmutter JS, Racette BA (2014) Disparities in deep brain stimulation surgery among insured elders with Parkinson disease. Neurology 82, 163-171. 
[163] Parker C, Philp I (2004) Screening for cognitive impairment among older people in black and minority ethnic groups. Age Ageing 33, 447-452.

[164] Jones RN (2003) Racial bias in the assessment of cognitive functioning of older adults. Aging Ment Health 7, 83-102.

[165] Jellinger KA (2017) Neuropathology of nonmotor symptoms of Parkinson's disease. Int Rev Neurobiol 133, 13-62.

[166] Pan S, Stutzbach J, Reichwein S, Lee BK, Dahodwala N (2014) Knowledge and attitudes about Parkinson's disease among a diverse group of older adults. $J$ Cross Cult Gerontol 29, 339-352.
[167] Dahodwala N, Karlawish J, Siderowf A, Duda JE, Mandell DS (2011) Delayed Parkinson's disease diagnosis among African-Americans: The role of reporting of disability. Neuroepidemiology 36, 150-154.

[168] Tan AH, Tan CT, Marras C, Loh KW, Wye Ho NW, Lim QH, Tan PW, Lim CC, Cheong YW, Kong ST, Schee JP, Tan KH, Soo SK, Vanderschaaf C, Lai Heong Lew S, Mahamad UA, Goh KJ, Yong HS, Lim SY (2015) Knowledge of Parkinson's disease in a multiethnic urban Asian setting. J Parkinsons Dis 5, 865-879. 